\title{
Using Crime Control Mechanisms in Yoruba Traditional Society as a Template for Redressing Security Challenges in Nigeria
}

\author{
Olúségun Peter Òké Ph.D. \\ Department of Religious Studies, \\ University of Ibadan, Ibadan, Nigeria \\ okeolusegun25@gmail.com \\ Doi: https://doi.org/10.46222/pharosjot.102.042
}

\begin{abstract}
Crime and its attendant fatalities has become a burning issue in Nigeria in recent times. It is a phenomenon that is bedeviling the nation and steps taken by government to prevent it seem inadequate as it continues to spread like a dry season fire. Existing studies on crime and its control have focused mainly on the use of modern methods which are at variance with the cultures of the various societies, while little attention is also paid to the crime control mechanisms of the traditional Yoruba society. The inability of government to tackle the menace of crime has led to palpable fears among the people as security of lives and property is perpetually threatened. This has impacted negatively on the country that is striving to be among the developed nations in the world. A qualitative method of research was adopted for this brief study. The paper argues that crime that has become the order of the day in Nigeria, came as a result of inter alia unemployment, poverty, selfishness and greed. This paper proffers a solution by proposing the use of traditional Yoruba crime control mechanisms with the modern one, side by side, to fight crime in Nigeria in order to foster the rapid economic and social development that everybody is longing for.
\end{abstract}

Keywords: Crime, Prevention Mechanism, Yoruba Traditional Society, Challenges, Nigeria.

\section{Introduction}

That Nigeria and the world over are facing a lot of security challenges today is no longer news. The Nigerian society today is characterized by all forms of insecurity issues which have threatened the corporate existence of the nation. Crime and criminality are not limited to the country alone as all nations in the world have their own share of this menace. Since crime, criminality and insecurity are a global phenomena, every nation of the world is trying as much as possible to develop mechanisms to deal with it using instruments of law that are peculiar to such societies. ${ }^{1}$ It is sad and quite unfortunate that people can no longer sleep with their two eyes closed as a result of the incessant attacks on the lives and property of people by these criminals. Their activities have left many homeless and lives are so lost so that getting an accurate figure will be very difficult to arrive at the real numbers on a daily basis. Opinions are rife that crime is both culture and gender based, and that crime and criminalities are more common among males, most especially the youth and the society where poverty is endemic. ${ }^{2}$ But recent developments,

${ }^{1}$ O.O.Olufayo and L.I. Jegede (2014). Redressing Security and Crime in Nigeria through Traditional Yoruba Social Values and Cultural Practices. Developing Country Studies. Vol.4 No.4.

${ }^{2}$ A. Giddens, M. Duneier and R. Appelbaum.(2006).Essential of Sociology. Instructor's Review Copy. New York. Library of Congress Catalogue.Pg.134. 
have indicated that crime is perpetrated by both sexes and even by the rich. Nigeria as one of the developing nations striving for greatness has continued to suffer a monumental setback in its efforts to be among great nations in the world and indeed the 'giant' of Africa. Criminal activities have hindered the developmental agenda of government at every level. The importance of security of lives and property in every human society cannot be overemphasized as absence of it will turn nations into brutish, nasty and short-lived entities as Thomas Hobbes affirmed. But traditional Yoruba society in the past, though it has experienced a few skirmishes and criminalities has developed a very strong and virile mechanism to fight crime and this has accounted for the relative peace enjoyed by the people. This is because cases of criminal activities and the culprits were promptly identified and dealt with head-on.

\section{What is Crime?}

Crime is an aspect of life that which all citizens must deal with as it seems to have been around as long as civilization itself. ${ }^{3}$ Crime has been given different definitions from various perspectives and by scholars who engage in its discussion. Oxford English Dictionary defines crime as an action of omission which constitutes an offence and is punishable by law. ${ }^{4}$ This definitions talks on crime as performance of an action or the failure of an individual to perform an action both of which can lead to punishment. Another definition of crime by Oxford Dictionary of Sociology is an offence which goes beyond the personal and into the public sphere, breaking prohibited rules or laws, to which legitimate punishments or sanctions are attached, and which requires the intervention of a public authority. This other definition approaches the phenomenon from a sociological point of view as the attention is not only to the act itself, but to the law itself and whose interests it seeks to protect. It makes a clear distinction between private offences and public offences that offend a broader set of social norms or values. ${ }^{5}$

\section{The Yoruba People of Southwest}

The Yoruba people constitute one of the major ethnic groups in Nigeria. A large number of them occupy the Southwestern part of the country. They are found in Ekiti, Ondo, Osun, Oyo, Ogun and Lagos states. We have others outside the western part of the states like Kwara and Kogi states. Many are also found in countries like Cuba, Brazil, Cotonou, Trinidad and Tobago and those others that scatter across the world, either in search of greener pastures or as a result of $18^{\text {th }}$ Century Trans-Atlantic slave trade that displaced many from their ancestral roots. ${ }^{6}$ Yoruba people are very hardworking, accommodating, industrious and resourceful. As a testimony of their hard work and resourcefulness, the people are found everywhere in the world making giant strides in the economic, social, political and educational development of the society where they find themselves. We have them as Medical Doctors, legal Practitioners, Engineers, Sports administrators and a host of others. ${ }^{7}$

\footnotetext{
${ }^{3}$ A.H.Escareno. The Cause of Crime

${ }^{4}$ The Scottish Centre for Crime and Justice Research. SCCJR. What is crime? University of Glasgow School of Education

${ }^{5}$ The Scottish Centre for Crime and Justice Research. SCCJR. What is crime? University of Glasgow School of Education.

${ }^{6}$ O.O.Olufayo and L.I. Jegede (2014). Redressing Security and Crime in Nigeria through Traditional Yoruba Social Values and Cultural Practices. Developing Country Studies. Vol.4 No.4

${ }^{7}$ A.J. Adebowale. (2010). The Yoruba People: Their Origin, Culture and Civilisation in Olatunde Olatunji,Ed. The Yoruba History, Culture and Language. Ibadan. Ibadan University Press.1996, 3-6, cited in Arinpe Adejumo,ed. A Postcolonial analysis of the Literary and Cultural Consequences of the abolition of the $18^{\text {th }}$ century transatlantic slave trade on the Yoruba of southwestern Nigeria. LUMINA, Vol. 21, No. 2.2094-1188.
} 


\section{Types of Crime}

It is important to, at this stage of the paper, to examine the various types of crime. This becomes necessary because of the various ways in which offences that are criminal in nature are perpetrated on a daily basis in Nigeria. The trend at which criminal activities are performed is a pointer to the fact that nobody is safe any longer. Crime has become a recurring decimal and its control has remained elusive as a result of ineffective security apparatus. ${ }^{8}$ This is why efforts will be made here to discuss various types of crimes that are committed for purposes of emphasis.

Armed Robbery: Armed robbery is as old as mankind itself, and it characterizes all known societies (both developed and developing societies). However, peculiarities and variations exist not only from society to society but also from time to time on how each society handles its culprits and how laws are enforced. ${ }^{9}$ Robbery is defined as the 'unlawful removal or taking of property or attempted removal or taking of property of another individual without his consent, by force or by threat of force immediately before or after the event. Armed robbery is a fast growing global antisocial behaviour cutting across cultures, races, colours and social classes with many lives (victims) and property affected. ${ }^{10}$ Several attempts have been made by scholars in the field of criminology in a bid to finding a plausible explanation and lasting solution to this criminal behaviour.

The menace is a prevailing social phenomenon that negatively affects the lives and social functioning of a significant number of people in Nigerian society. It involves stealing, during which force and violence or the threat of violence are employed. ${ }^{11}$ In Nigeria today, more than ever before, daily newspaper reports, television news headlines and radio announcements are awash with stories of one crime or the other, making both the rich and the poor to live always in perpetual state of fear because nobody really knows where and when these hoodlums they will strike. ${ }^{12}$ In various robbery incidences, innocents' citizens are killed, maimed to suffer, while one's livelong savings are lost within a twinkle of an eye. ${ }^{13}$ The current scourge of armed robbery in Nigeria is as a result of past socio economic and political experiences with its colonial master. This has continued to be a threat to the country's socio economic and political development. ${ }^{14}$ Armed robbers attack their victims in various ways. This could be through waylaying the victims on the highways and at transit points; storming residences, commercial buildings, public and private establishments, religions places; by system of maneuvering geared towards outwitting

\footnotetext{
${ }^{8}$ B.Owumi.and J.O.Olusegun. (2013). Traditional Values, Beliefs and Reliance on Indigenous Resources for Crime Control in Modern Southwest Nigeria. African Journal Review. An International Muiltidiscplinary Journal, Ethiopia.Vol 7(1), No.28.

${ }^{9}$ G.U. Okolo. (2002). Social Work: An Introductory Analysis. Calabar: University of Calabar Press.

10 S. E.Otu and O. E .Elechi. (2015). Pathways and trajectories to lifecourse persistent armed robbery offending behaviour in contemporary Nigeria: Examining the predictors and the risks factors. International Journal of Criminal Justice Sciences, 10(1), 10 31.).

${ }^{11}$ A.N. Lumun and et.al. (2013). The Effects of Armed Robbery in Nigeria. IOSR Journal of Humanities and Social Science (IOSR-JHSS). Vol. 11, Issue 3 (May. - Jun. 2013), PP 57-59 e-ISSN: 2279-0837, p-ISSN: $2279-0845$. www.iosrjournals.org. Retrieved 12/9/2021.

${ }^{12}$ G.U. Okolo. (2002). Social Work: An Introductory Analysis. Calabar: University of Calabar Press

${ }^{13}$ B.A. Skidmore and M.G. Thackeray (1982). Introduction to Social Work. New Jersey: Prentice-Hall.

14 S. Egwu. 2003. Armed Robbery in the Southwestern States of Contemporary Nigeria Contemporary Nigeria: A

Crininal and Criminology Analysis,
} 
victims skilfully; and holding up banks. ${ }^{15}$ Most armed robbers usually plan their activities and celebrate their offending behaviour and exploits in public and secluded places where they use and abuse psychoactive substances, particularly marijuana and high-powered alcoholic drinks.

This behaviour often predisposes them to victimisation or increase their chances of victimising others. ${ }^{16}$ House breaking is very minimal in recent times as people no longer keep money at home. But, most of their victims include those residing in a deviant/criminal neighborhood (viz: slums, shanties and ghettos) and flashpoint areas. Carrying expensive portable items such as laptops, smartphones, expensive articles of jewellery and large sums of money in crime-prone areas without capable guardians or hardening the targets (the said items) also predisposes individuals to armed robbery attacks. Whatever may be the cause of armed robbery in Nigeria, and whatever nature or form or shape it may assume, armed robbery is an antisocial behaviour that leaves negative effects on the society and among its members A single crime, observed Skidmore, may alter the existence of a particular family and as families become weak and filled with tension and chaos, society is injured and social life is threatened. ${ }^{17}$

Assault: An assault is a violent, life-threatening situation. When one is assaulted, one faces death. Even when one is not seriously or permanently injured during the assault, one has to deal with the possibility of death and fears of leaving loved ones behind. These and other aspects of assault can have a great emotional and psychological impacts on the victim and the family members. Assault are of two types, the aggravated and simple assault. The aggravated assault can be defined as an unlawful attack on another person for the purpose of causing severe physical injury. It is referred to as aggravated assault when it includes the use of weapon or any other instrument that could cause death or serious physical or bodily harm to the victim while simple assault is an attempt or threat to inflict injury without the use of weapon. Cases of assault are increasing at an alarming rate in Nigeria, more so now than before as a result of failure of government to address issues of youth restfulness, poverty and bad governance. Even when assault victims do not sustain extensive injury or loss, they are forced to suffer threats of violence and physical harm at the hands of their assailants. After an assault, the victim may be fearful of being assaulted again, have nightmares or flashbacks about the assault experience, find that he or she startle more easily at little noises or abrupt movements. One can also feel humiliated or rejected by family members or acquaintances.

White Collar Crime: The sociologist Edwin Sutherland coined the term white collar crime in a speech given to the American Sociological Society in 1939. He defined white collar crime as crime committed by a person of respectability and high social status in the course of his occupation. It is also defined as an illegal deviance perpetrated by those who had the tools to achieve the goals which their society taught them to desire, and had, in fact, already used them to that effect. It can also be defined as financially motivated, nonviolent crime committed by individuals, business and government. ${ }^{18}$ This is a type of crime carried out by people in the more affluent sectors of the society. It is a criminal activity that includes tax fraud, illegal sales practices, land fraud, embezzlement, money laundering, financing terrorism, falsifying company account and illegal environmental pollution. White collar criminals in most cases escape prosecution because of their

\footnotetext{
${ }^{15}$ S.K.Mukherjee et.al. 1987, The Size of the Crime Problem in Australia, Australian Institute of Criminology, Canber

16 G.Jensen, and D. Brownfield. (1986). Gender, lifestyles, and victimization: Beyond routine activity theory.

Violence and Victims, 14, 85-99.

${ }^{17}$ B.A. Skidmore and M.G. Thackeray (1982). Introduction to Social Work. New Jersey: Prentice-Hall

${ }^{18}$ A. Giddens, M. Duneier and R. Appelbaum (2006).Essentials of Sociology. Instructors's Review Copy. New

York. W.W .Norton \& Company.
} 
class and status in the society and their influence in the implementation and the administration of law. White collar crime is seen as a crime because it violates the ideal ethical conduct inherent within the principle of what is known as natural law. Natural law focusses on behaviours that are defined as wrong because they violate the ethical principle of a particular culture, or group. Therefore white collar crime is a threat to any nation such as Nigeria that is striving for greatness. ${ }^{19}$

Corporate Crime: This is another type of crime that is performed by corporate bodies in the society. Criminal activities that fall under this category are pollution, product mislabeling and violation of health and safety regulations. These criminal activities affect larger number of people than petty criminality. Corporations produce cars we ride and process food we eat. They also as a matter of fact, do not adhere strictly to legal regulations that apply to them thereby causing a lot of health problem on the members of the society. This type of crime is not confined to an individual, but instead pervasive and widespread. The moral fabric of society is eroded and this is mainly due to a lack of ethics and the absence of a moral compass in society ${ }^{19 a b c}$. There is a difficulty in tracing the culprits of corporate crime because of the distance in time and space unlike the traditional crime that there is a close proximity between the victims and the offenders. This makes it hard to realize the havoc they have caused the society. ${ }^{20}$

Organized crime: This involves forms of activities that have some resemblance with the orthodox businesses that are illegal in nature. It embraces illegal gambling, drug addiction, prostitution, large scale theft. Activities of organized crime are increasingly becoming international on a daily basis in scope with the help of information technologies. Organized criminal groups form transborder alliance involving activities ranging from the narcotics trade to counterfeiting to smuggling immigrants and human organs. They now operate in flexible international network rather than within their own territorial realms. ${ }^{21}$

Computer crime: Cybercrime is an act of crime that involves computer and a network. The computer may have been used in the commission of a crime, or it may be the target. Net crime refers to criminal exploitation of the internet. Examples of the computer crime include cyber terrorism, cyber warfare, harassment on the internet, spam and internet fraud. ${ }^{22}$

Corruption: This is the use of power by government officials for illegal gain. It includes bribery, embezzlement etc. ${ }^{23}$ The high level of corruption in Nigeria has robbed the country of developing a vibrant economic base in spite of its abundant natural resources. Massive corruption is perpetuated in every sector and this has permeated the entire social structure of Nigeria. Funds meant for development projects which could have generated employment opportunities for the teeming youth have been misappropriated, embezzled or diverted to private accounts. Corruption is a crime because of its negative impact on the society. While few members of the society are

\footnotetext{
${ }^{19}$ L. Girla and J. Rub. 2015. White Collar Crime: Definitional Issues and Classification. Revista Nationala De Drept. Retrieved 15/9/2021. ${ }^{19 a b c}$ Nicolaides.

${ }^{20}$ A. Giddens, M. Duneier and R. Appelbaum (2006).Essentials of Sociology. Instructor's Review Copy.New York. W.W .Norton \& Company.

${ }^{21}$ A. Giddens, M. Duneier and R. Appelbaum (2006).Essentials of Sociology. Instructors Review Copy. New York. W.W .Norton \& Company.

22 S. Thotakura. 2014. Crime: A Conceptual Understanding: Crime, Criminology, Causes and Types.www.researchgate.net/publications/270238380. Retrieved on 11/8/2021

${ }^{23}$ S. Thotakura. 2014. Crime: A Conceptual Understanding: Crime, Criminology, Causes and

Types.www.researchgate.net/publications/270238380 .Retrieved on 11/9/2021
} 
living large from the money realized as a result of corruption, others that in the majority continue to wallow in abject poverty. ${ }^{24}$

Victimless crime: This type of crime is called victimless because there is no identifiable victim. They are acts that are committed against the moral values of an individual. Commission of crime like prostitution, illegal gambling, illegal drug use are examples of crime under this category. ${ }^{25}$

Kidnapping: The term kidnapping is complex and transitional due to its state-to-state scenario as well as jurisdictional criteria. The phenomenon is described as abducting or capturing away of persons intentionally to deprive them of their freedom. Generally, it comprises capturing and detaining an individual against his or her will, usually in an extension of other criminal intentions. ${ }^{26}$ Kidnapping can be for extortion. This is where ransom is paid to influence business decisions or to obtain commercial advantage. Kidnapping can also be between or within criminal groups. This is carried out for debt recovery or secure an advantage in a criminal market. Another category of kidnapping is for sexual exploitation and for political or ideological purposes. Kidnapping became rampant in Nigeria during the agitation for resource control in Niger-Delta around the early 1990. The militants vandalized and kidnapped high profile individuals and foreign expatriates to drive home their demands. Many local business persons were kidnapped for ransom. The effect of kidnapping on individual and society is better imagined than experienced. ${ }^{27}$

\section{Causes of crime}

Crime is a perennial and a global phenomenon. Its global nature makes it a herculean task to tackle in spite of efforts of successive governments both in Nigeria and other nations of the world. This now raises the question among scholars in criminology and agencies of government that deal with crime, as to what the causes of crime are and what makes it so difficult to address. This is the more reason, why this section focusses on the causes of crime in Nigeria. Knowing full well that identifying the cause(s) will give the stakeholders a leeway on how it will be addressed in order to ensure peaceful society where crime and its attendant effects will be highly reduced, if not totally eradicated.

\section{Poverty}

Poverty is a denial of choices and opportunities, a violation of human dignity. It means lack of basic capacity to participate effectively in the society. It can also be said to mean not having enough to feed, clothe a family, not having a school to go to or not having a job to earn a living. ${ }^{28}$ According to Scott and Marshall, poverty is a situation in which resources, usually material but sometimes cultural, are lacking. It is a condition of having insufficient resources or income. In its most extreme form, poverty is a lack of basic human needs such as adequate and nutritious food,

\footnotetext{
${ }^{24}$ E.E.Okafor: 2005. Executive Corruption in Nigeria: A Critical Overview of its Socio-Economic Implications for Development. .Alt. J. Psychology Studies Association. Issues 8(1):21-41

${ }^{25}$ S. Thotakura. 2014. Crime: A Conceptual Understanding: Crime, Criminology, Causes and Types.www.researchgate.net/publications/270238380.

${ }^{26}$ C.U. Ugwuoke. 2011. Nigeria and the menace of kidnapping. The way forward. The Nigerian Journal of Research and Production. Vol. 18 (2)1-14).

${ }^{27}$ O.Aigbovo and O. Eidenoje: Theorising Nigerian Crime Problems. http://dx.org/10.4314/mir.v10i1.7. Retrieved 23/9/2021.

${ }^{28}$ J. Scott and G. Marshall (eds.) 2005. Oxford Dictionary of Sociology. New York: Oxford University Press.Cited in O.O. Familusi and O.P.Oke.2011. A Christian Dimension to Poverty Discourse in Nigeria. Orita:Ibadan Journal of Religious Studies, University of Ibadan.XL111/2.
} 
clothing, housing, clean water and health services. ${ }^{29}$ Poverty is a multidimensional phenomenon and efforts made over the years by government, Non-Governmental organizations (NGO's) and corporate bodies to address it has not paid off. In Nigeria, widespread of unemployment and severe poverty is a reality. There are many effects associated with poverty, most especially in Nigeria. One of the main effects of poverty is crime. This considerable high level of poverty in Nigeria calls for policy attention in addressing the menace due to the negative spillover effects it is having on the Nigerian society.

Poverty increases the likelihood of criminal activities. In fact, there is a long run relationship between poverty and crime in Nigeria due to the fact that citizens do not have enough income to meet the basic necessities of life. ${ }^{30}$ The failure of government to provide these necessities of life to the members of the public propel people to seek alternative means of survival, which in most cases are crime. Apart from lack of basic amenities for the people, lack of education, corruption, unstable political environment are other remote causes of poverty. ${ }^{31}$ It will be very difficult if not impossible to preach morality to a hungry and jobless man who would do anything including criminal activities such as robbery and thuggery to keep body and soul together. Therefore, a poor man has nothing to lose except his poverty. ${ }^{32}$ Poverty is endemic in the nation because the wealth of the nation are not well distributed as evident in the marginalization of some groups and monetization of political posts, which has led to a concentration of national or state resources in the hands of few individuals, who squandered them at the expense of the poor. ${ }^{33}$

\section{Unemployment:}

Unemployment is a situation where people are willing to work but could not find employment. On the other hand, crime happens when an offender uses or threatens to use violent force upon the victim. Youth unemployment has been on the increase in recent time. Unemployment appears to be the root cause of criminal activities in Nigeria as an idle hand is a devil's workshop. It is evidently clear that youths who are not employed are more likely to be perpetrators as well as victims of criminal activities. ${ }^{34}$ Causes of crime in Nigeria are not far-fetched as studies have been associated with rising in youth unemployment and the increase in the crime rate. Youths are creative with high energy and the greatness of any nation, is determined by the quality of the youth in such a nation. But in a country, where the energy of the youth that constitute the majority are not channeled properly, it will lead to social unrest, crime and instability. The rise in violent crimes like robbery, kidnapping, thuggery, terrorism committed by the youth is a sign of a 'gap' in the society. Expectations are high from the youth but the means on which to achieve this are limited, they are therefore forced to achieve this goal by illegal means to fulfill societal

\footnotetext{
${ }^{29}$ C.Uchah.2010. Poverty in Nigeria: Some Dimensions and Contributing Factors. Global Majority E -Journal, Vol.1, No. 1.

${ }^{30}$ A. Adekoya, and N. Abdul-Rasak .2016.Effect of Crime on Poverty in Nigeria. Romanian Economic and Business Review. Cited in C.O. Iheonu and N.E. Urama. 2019. Addressing Poverty Challenges in Nigeria. Afriheritage Policy Brief. African Heritage Institution.

${ }^{31}$ M.Omoniyi.2013. The Role of Education in Poverty Alleviation and Economic Development: A theological Perspective and Counselling implications. British Journal of Arts of Arts and Social Sciences, 15(11).

${ }^{32}$ O.Olukunle. 1986. Ethical Revolution: The Newest Doubtful Craze in Town. In S.O. Abogunrin (Ed.) Religion and Ethics in Nigeria. Ibadan. Daystar Press.

${ }^{33}$ O.O.Familusi and O.P.Oke.2011. A Christian Dimension to Poverty Discourse in Nigeria. Orita: Ibadan Journal of Religious Studies, University of Ibadan.XL111/2.

${ }^{34}$ E.E. Okafor.2011. Youth Unemployment and Implications for Stability of Democracy. In Nigeria journal of Sustainable Development in Africa. Vol.13, No.1.
} 
expectations. ${ }^{35}$ Unemployed youths are ready made instruments in the hands of politicians who use them to foment trouble during elections by undermining democratic practices thereby constituting a serious threat to the country peaceful co-existence.

\section{Single-Parent Family}

Many children grow up in single parent family, meaning that often they grow up in a family with only one biological parent present. In the recent times, the number of single parents are on the rise and many factors are responsible for this. The birth of a child naturally is between two parents, the husband and the wife. But, an occasion may arise when by divorce, separation or death, they are not together again. The responsibility of taking care of the child rest on either the mother or the father. Raising children in a single parent family can be so challenging, which also entails a risk that jeopardize adolescent's future life chances. One other risk apart from its effects on children's emotional well-being, cognitive development and school performance is the involvement in criminal behaviour. For instance, children that have weaker attachment bonds to their parents might be stimulated to spend more time in criminogenic settings instead of with their parents. This makes them to get involved in criminal activities. ${ }^{36}$

\section{Drugs}

Drugs can be defined as any substance or mixture of substances manufactured, sold or advertised for use in the diagnosis, treatment, mitigation or prevention of any disease disorder, abnormal physical state, or the symptoms thereof, in man or in animals, restoring, correcting or modifying organic functions in man or animals; disinfection, or the control of vermin, insects or pests; or contraception. ${ }^{37}$ Another definition of a 'drug' that is more relevant to this paper is the one offer by Siro $^{38}$ as any habit- forming substance that directly affects the brain or the body function, like mood, perception or consciousness that has a potential for misuse and may be harmful to the user and the society. With these definitions above, a wide range of areas is covered. More than ever before, the misuse, abuse of drugs has become a menace in the country today as both old and young are involved in the criminal behaviour. Most people are of the opinion that taking of drugs is a way of attaining the desired moods or psychological well-being, perhaps a universal desire. They believe that when they fall into undesirable mood, they can alter their own feelings with drugs. ${ }^{39}$ Drugs and their abuse is on the increase and youths are rating the high risk category and its menace. Drugs and solvent use is extremely high among the street youths, and secondary scholars and students of higher institutions in the country, and this is responsible for the crime and criminalities taking place in various Nigerian cities. Drug abuse and crime are like Siamese twins that seems very difficult to separate. Abuse of drugs aids crime and the continuous

\footnotetext{
${ }^{35}$ O.O.Ajaegbu.2012. Rising Youth Unemployment and Violent Crime in Nigeria. American Journal of Issues and Humanities. Vol. 2(5).

${ }^{36}$ J.Kroese.et.al.2020. Growing up in Single-Parent Families and the Criminal Involvement of Adolescents: A Systematic Review. Psychology, Crime and Law. United Kingdom. Informa UK Limited, Trading as Taylor \& Francis.

${ }^{37}$ Federal Ministry of Health. 2005. National Drug Policy 2005. Federal Ministry of Health, in Collaboration with World Health Organisation. In M.D. Hussein, J. I. Mukhtar and M.B.Umar.2007. Drug-Crime Nexus Nigerian Youths: A Solution through Crime Prevention Strategy. KASU Journal of Social Sciences

${ }^{38}$ A.A.Siro (2014). Drug Abuse and Political Thuggery among the Youth in Kano Metropolis: A Modern Civilisation or Resource Mismanagement? Journal of Studies in Social Sciences. Vol.7 (2). In M.D. Hussein, J. I. Mukhtar and M.B.Umar.2007. Drug-Crime Nexus Nigerian Youths: A Solution through Crime Prevention Strategy. KASU Journal of Social Sciences

${ }^{39}$ M.B. Clinard, and R.F. Meier. 2011. Sociology of Deviant Behaviour (14 ${ }^{\text {th }}$ Edition) Belmont, CA: Wordsworth Cengage. ). In M.D. Hussein, J. I. Mukhtar and M.B.Umar.2007. Drug-Crime Nexus Nigerian Youths: A Solution through Crime Prevention Strategy. KASU Journal of Social Sciences.
} 
usage of it can lead to drug addiction. ${ }^{40}$ The illegal use of drugs such as cocaine, heroin, marijuana and even alcohol goes parri passu with the commission of criminal activities. Violent crimes committed by the youth in the country against persons are found to be more committed by those who abuse drugs. Drug abuse is associated with criminal offenses that can lead to reckless driving and traffic violations and consequently to, accident injuring people or loss of lives. ${ }^{41}$

\section{Greed and Selfishness}

Greed is a social cancer said to be at work in a person when that person has excessive desire for something be it food, money, wealth or anything else, which in reality he or she does not need or need as much as they believe. Often it is excessive and selfish desire for money, wealth, power, influence, without thought about the after effects. Selfishness is lack of consideration for other people. Selfishness is a subtle but fertile soil for violence and criminal activities. Man is a social being- a being that lives, works and grows in the midst of others; in taking action, the interest of others should be considered. But when selfishness takes over an individual, he ignores totally or considers less this aspect of his social life and focuses on the self, and his actions often become offensive to others arouse in them negative reactions which must be violent in varying degrees. As a result of greed and selfishness on the part of those at the corridors of powers; the endless promises of political office holders has not translated to a better life to the citizens, youths resort to criminal activities to make ends meet. ${ }^{42}$

\section{Mental Disorderliness}

Weak minded persons tend to be involved in criminal activities very easily. Any person who suffers from mental disorders tends to be involved in some illegal and violent activities. Individuals in this category become unassociated, irritable, cruel, obstinate, lonely, full of feelings of revenge and uncontrolled in their behaviour. They can resort to criminal activities as an abnormal persons possesses degree of freedom, irresponsibility, revolt, homicidal tendency, suspicion, lack of control, sadism, and naughty. He indulges in gambling, cigarette, smoking narcotic drug consuming, breaking things, absconding from the home, prostitution and stealing etc. ${ }^{43}$

\section{Crime Control Mechanisms of Traditional Yoruba Society.}

There is no society that is totally free of crime and criminality but the degree of its presence or occurrence varies from one society to other as it depends on the mechanisms put in place to checkmate the trend and incidence. ${ }^{44}$ For instance, before the introduction of modern methods of crime control which seems not to have achieved its desired goal as cases of criminal behaviours are on the increase. Though it is of a fact that the Yoruba traditional society did not have a written law to guide their conduct, yet it had a well-structured crime control mechanisms for the maintenance of social order which helped the communities to leave in relative peace as against what we are experiencing in Nigeria today. This code of conduct constrains individuals to live in

\footnotetext{
${ }^{40}$ U.S. Karofi .2010. Drug-crime nexus: An alternative explanation. Bayero Sociologist: A Journal of Sociological Studies.Vol.1.3.

${ }^{41}$ A.M. DUkku.2012. The Availability-proneness theory: The Gadagi Experience in Kano, Nigeria. Bayero

Sociologist: A Journal of Sociological Studies.Vol.1.3.

${ }^{42}$ P.F.Fagan. The Root Causes of Violent Crime: The Breakdown of Marriage, Family and Community. http:www.heritage.orgedu/bpi/pdfs/crime report.pdf.

43. Thotakura. ( 2014). Crime: A Conceptual Understanding: Crime, Criminology, Causes and

Types.www.researchgate.net/publications/270238380

${ }^{44}$ B. Owumi and J.O. Ajayi. (2013).Traditional Values, Beliefs and Reliance on Indigenous Resources for Crime Control in Modern Southwest Nigeria. African Research Review. An International Multidisciplinary Journal. Ethiopia. Vol.7 (1), Serial No.28.
} 
conformity with the well-being of the society. The components of the code have been transmitted conventionally from one generation to the other. Abnormal behaviour which is not in conformity with the norms of the society are criminal acts. ${ }^{45}$ There were various traditional mechanisms through which Yoruba traditional society controls crime. This includes the family court (Ile ejo agbo ile), medicine men (elegboogi), Diviner (Babalawo), Banishment/Isolation, satirical song and culture of shaming. ${ }^{46} \mathrm{Few}$ of such crime control mechanisms shall be considered here.

The family court (Ile ejo agbo ile): The elders at the family, ward or quarter level were seen as the representatives of their ancestors, and as such, they are saddled with the responsibility of maintaining law and order at the family level and society at large. ${ }^{47}$ At the family court, cases handled include quarrels among wives, abduction, adultery, wife battery, family inheritances dispute, petty theft and destruction to farm tree. The family heads serve as the adjudicators. However, cases involving two families were usually transferred to Oba's court. ${ }^{48}$ In effect, the family court mitigate and adjudicate in criminal cases. ${ }^{49}$

Satire and Culture of Shaming: Satire can be described as the use of irony, ridicule, mockery, caricature, burlesque, derision, sarcasm, lampoon and parody to denounce vice and folly in the society. ${ }^{50}$ While shame is a painful feeling of humiliation or distress caused by the consciousness of untoward behaviours, they serve the purpose of exercising control towards maintenance of law, order and peace in Yoruba society. Since there are moral standards of behaviour which society sets for its members to follow, and failure on the part of anyone to follow the moral standard, such an individual will be publicly ridiculed. They are cultural practices found in Yoruba society where communities come together to show their displeasure towards any person or group of people who did something deemed to be unacceptable. Groups of young men and women would gather in front of the person's house and sing songs of derision about their misdeeds. Theft, adultery, swindling, insubordination, or any other actions considered to be unworthy of a member of the community were the common offences. ${ }^{51}$ They go with different types of objects they can lay their hands on ranging from stones, sticks, bottles, tree branches and so on. The custom of 'blocking' the house of those who committed criminal activities was accompanied with satirical songs to shame the offenders and serve as deterrent to others. ${ }^{52}$ Good conduct is praised and encouraged while bad conduct is openly denounced. This measure in crime control helps in maintaining social order and ensured conformity. ${ }^{53}$

\footnotetext{
${ }^{45}$ S. A.Adewale.(1994) Crime and African Traditional Religion. In Orita: Ibadan Journal of Religious Studies.XXVI/1-2.

${ }^{46}$ A.A. Achu, E.J. Owan and U.F. Abul (2013). Traditional Methods of Crime Control and Community Security in Odukpani Local Government Area of Cross River State, Nigeria. In IORS Journal of Humanities and Social Sciences (IOSR-JHSS). Vol.14, Issue 5.

47. O.B.Olaoba, (2002). Yoruba Indigenous Court. In Yoruba Legal Culture. Ibadan. FOP Press.

${ }^{48}$ O.B.Olaoba, (2002). Yoruba Indigenous Court. In Yoruba Legal Culture. Ibadan. FOP Press.

49 T.Oludayo. (2019). How Traditional Beliefs and Systems are used to fight crime in parts of Lagos. The Conversation: Academic Rigour, Journalist Flair.

${ }^{50}$ A.Adejumo,(2007). Satire as a form of Social Control: Its Manifestations in Yoruba ritual and festival Songs. Orita: Ibadan Journal of Religious Studies.XXXIX.

${ }^{51}$ E.B.Fayemi, (2019). Shame! Vanguard. https://www.vanguardngr.com/2019/09/shame.Retrieved 25/9/2021

52 O.P.Oke, (2017). Edi Festival Songs and the control of Deviant Behaviours in Traditional Marriage Institution in Origbo-Meje, Osun State. A Ph.D thesis Submitted to the Department of Religious Studies, University of Ibadan

${ }^{53}$ A.A. Achu, E.J. Owan and U.F. Abul (2013). Traditional Methods of Crime Control and Community Security in Odukpani Local Government Area of Cross River State, Nigeria. In IORS Journal of Humanities and Social Sciences (IOSR-JHSS). Vol.14, Issue 5.
} 
Banishment: According to the Cambridge Dictionary, banishment is defined as sending someone away, especially from his country and not allow him to come back. This method was copiously used in the Yoruba traditional societies in the past, most especially for hardened criminals who are in the habit of perpetually terrorizing the communities either on a temporary or permanent basis. Banishment on temporary basis takes place when the offences are persistent stealing, repeated cases of adultery and manslaughter. On the other hands, offences that attracted long term banishment are murder, culpable homicide, poisoning and treasonable felony. Banishment was dreaded by the people because of the disgrace that it brought to the culprit and family members. ${ }^{54}$

Ostracism: This is another yet crime control mechanism used by the Yoruba people. It involves a deliberate isolation of an offender for a period of time. This is usually carried out in order for the offender to realize the gravity of his action. The offender experiences a lot psychological and social pain coupled with the fact that he or she was going to a place to start a new life away from his family members. The offender could still come back to the community after ostracism that is usually a fixed period. Offences that attract punishment include adultery and habitual stealing, thuggery and so on. ${ }^{55}$ This type of punishment for offenders is mostly used where conflicts or criminal injury are deemed to be beyond human understanding. It is also used where the people involved feel disgruntled with the judgment received the decision and the legal processes of the Baale or the Oba as the case may be. ${ }^{56}$

Oath-Taking: An oath is a solemn promise or expression of commitment in which religious words express how a person intends to behave in a given circumstances. An oath is a call on the divine to witness to the truth of a statement or the sincerity of a promise. In traditional Yoruba society, an oath is a formal solemn agreement between two individuals, groups, communities that has strong antecedent in the tradition of the people. ${ }^{57}$ Oaths are generally used as a curse where there is doubt or mystery over an issue, and the parties involved are unwilling to compromise and there is no clear-cut evidence. It is used most especially when cases of stealing or adultery are involved. ${ }^{58}$ Suspects are made to swear to ascertain their innocence or guilt. Oath taking is very potent, to the extent that people were scared to commit crime because of the resultant effect.

Ritual: This is a solemn ceremony consisting of series of actions performed according to a prescribed order. In Yoruba society, anybody who performed an act that is in contradiction with the norms of the society is condemned and publicly ridiculed. In most cases, rituals are performed to detect a thief and recover the stolen property. They commit the culprit to the gods for punishment, and in some cases, the thief is exposed publicly and made to confess. He may be subjected to prolonged torture, illness, paralysis to the point that the diviners are consulted for the

\footnotetext{
${ }^{54}$ C.U. Ugwuoke, (2002). Methods of Crime and Social Control in Nigeria. A Traditional Perspective. In O.J.Onwuka (ed.) Nigeria Peoples and Cultures: Historical and Socio-Structural Perspectives. Enugu, Echrisi and Company, Nigeria

${ }^{55}$ W. Clifford, (1974). An Introduction to Africa Criminology: Nairobi: African University Press.

${ }^{56}$ T.Oludayo. (2019). How Traditional Beliefs and Systems are used to fight crime in parts of Lagos. The Conversation: Academic Rigour, Journalist Flair.

57 J.K. Ayantayo, (1999). Religious Ethical Issues in the oath of the Nigerian Constitution. In Orita: Ibadan Journal of Religious Studies.XXIV.

58 T.Oludayo. (2019). How Traditional Beliefs and Systems are used to fight crime in parts of Lagos. The

Conversation: Academic Rigour, Journalist Flair.
} 
cause of the misfortune. The public disgrace for the offender serves as deterrent to others who may have the mind of committing such anti-social behaviour. ${ }^{59}$

Age Grade: In Yoruba traditional society, the age grade played important role in the control of crime and criminal activities. It is a group charged with responsibility of keeping the society safe and secure. Age grade usually had its own control mechanism, its rules and regulation is to reinforce certain positive behaviours and punish others. For an individual to maintain membership, one has to act in a disciplined manner. ${ }^{60}$ A typical example of this group is found in Ilogbo Ekiti in Ekiti state where a group of youth who are of the same age bracket are called Egbe Awere and Origbo in Irun Ekiti. This category of youth are between 20-35 years. They are a fearless and committed set of people who always move around with supernatural powers to face any criminal that was proving difficult in the community. To join the group, an initiation must be carried out. Every male adult in the community must pass through the Egbe Awere in order to demonstrate their support and loyalty to the community. The fear of the age grade was the beginning of wisdom as they did not spare anybody. The only people that can be spared are those that are not found wanting in the discharge of their duty. ${ }^{61}$

\section{The Effectiveness of Modern Crime Control Mechanisms in Nigeria}

Modern crime control mechanisms rely on the law and official government agencies like the court of law, the Nigerian Police, Economic and Financial Crime Commission (EFFCC), Independent Corrupt Practices and other Related Offences Commission (ICPC) and so on. ${ }^{62}$ These are institutions of the state established to control human conduct. In modern society, criminal laws are enacted to replace the traditional rules and regulations. Anyone guilty of any criminal offence is charged in line with the modern crime control mechanisms put in place by the government at various levels. It is quite unfortunate therefore to note that the modern crime control mechanisms are at variance with the peculiarity of the traditional society ways. It also allowed for a very weak traditional society that encourages indolence and which has relegated the cherished traditional values and norms to the background. ${ }^{63}$

\section{Conclusion}

The paper has examined the various types of crime, causes of crime and the crime control mechanisms put in place by traditional Yoruba society. Traditional methods of crime control in the past was very effective and this resulted in the relative peace experienced by the people as canvassed in the paper. It is unarguably clear that those mechanisms for controlling crime in the past, have been taken over by the court of law and government agencies. These changes came as a result of the introduction of Christianity, western education, colonialization and globalization.

\footnotetext{
${ }^{59}$ S. A.Adewale, (1994). Crime and African Traditional Religion. In Orita: Ibadan Journal of Religious Studies.XXVI/1-2

${ }^{60}$ O. Friday and E.O. Eze, (2019). Crime Control in Traditional African Societies: A Review of Crime Control in Nigeria. In Journal of Social Service and Welfare. Vol.1, Issue 2. Sryahwa Publications.

${ }^{61}$ B. Owumi and J.O. Ajayi. (2013).Traditional Values, Beliefs and Reliance on Indigenous Resources for Crime Control in Modern Southwest Nigeria. African Research Review. An International Multidisciplinary Journal. Ethiopia. Vol.7 (1), Serial No.28.

${ }^{62}$ E.C. Lamber, O.O. Elechi, (2009). Formal and Informal Crime Control View in Nigeria \& USA. An Exploratory Study among College Students. Journal of Ethnicity in Criminal Justice. Nol. 8, Issue 2.

${ }^{63}$ B.N.Onyima. Traditional Methods of Social Control in Afikpo North Local Government Area, Ebonyi State, Southeastern Nigeria.
} 
In view of the foregoing discussions, the following recommendations are made:

\section{Recommendations}

Government should increase (recruit) the number of well-trained police and provide them with modern technical equipment such as helicopters, effective communication devices, surveillance cameras, sophisticated arms and ammunition, trained dogs, adequate patrol vehicles, etc. The society is becoming more complex on a daily basis and a responsible and responsive government should make the protection of lives and property a top priority. Training and re-training, seminars, conferences and workshops for police should be organized periodically on new methods for fighting crime. This will go a long way in helping the police officers to enrich their knowledge and learn new ideas on the modern techniques of combating crimes. It is not out of place for government to sponsor some of them to undergo training in advanced countries. Moreover, all Nigerian citizens should volunteer information that could lead to arrest of suspected armed robbers and other criminals. The police on the other hand must establish a friendly relationship with the public so that members of the public can be able to volunteer information confidentially.

The role of traditional rulers in this regard cannot be over-emphasized. These are the custodians of morality and culture of the people. Their advices and intervention are necessary to develop the community. Considering the importance of the indigenous mechanisms in controlling crimes in prevailing circumstances, there is the need for government to give special recognition and to support the promotion of every state traditional security apparatus peculiar to them. This will play a complementary role with the modern crime control systems like the police. Instead of spending billions of naira on the purchase of high-tech equipment, working with the indigenous people will enhance the detection of crime and extremism, help to gather intelligence information and build partnerships and thus enhance the confidence with the public.

Youth unemployment and its relationship with attendant crime are part of major social problems affecting the growth and development of this country. Government as a matter of urgency should invest massively in agriculture and encourage youth in this direction. This can be done through the provision of soft loans and the establishment of farm settlements for the seething number of youths that may contribute their quota to national development. To fight corruption and corrupt activities, government should create an enabling environment for industries to survive in and to thus remain sustainable. A situation where companies that are supposed to employ the youth are closing down is not good for the country. Government must ensure the survival of industries and work in partnership with them.

Government must be ready to make available everything possible that will make life worth living for the citizens so that the tendency to commit murderous crime will be reduced in our society, because we cannot say that capital punishment is not justifiable and allow murderer to go scot free.

Without adequate funding by the government, an anti-drug policy cannot be successful. There should be a deliberate effort by government to fight drug abuse in Nigeria through the funding of National Drug Law Enforcement Agency (NDLEA). This will help the agency to achieve proper and sophisticated training for its staff.

To achieve peace, law and order in our society, the current relegated status of traditional status of traditional crime control mechanisms in Yoruba society should be reviewed. There should be an integration and co-existence between traditional and modern crime control mechanisms to ensure a holistic crime control system in Nigeria. Finally, parents must normatively ensure the 
education and social progress of their children at all costs, even though some may be under foster care by relatives. An untrained child, lacking in normative values is a potential decadent individual in the near future and such a child may not be socially valuable and would be a cause of social stigma to his or her immediate social environment and create havoc with an ethical foundation to guide him or her.

\section{References}

Achu, A.A., Owan, E.J. \& Abul, U.F. (2013). Traditional Methods of Crime Control and Community Security in Odukpani Local Government Area of Cross River State, Nigeria. In IORS Journal of Humanities and Social Sciences (IOSR-JHSS), 14(5).

Adebowale, A.J. (2010). The Yoruba People: Their Origin, Culture and Civilisation in Olatunde Olatunji, Ed. The Yoruba History, Culture and Language. Ibadan. Ibadan University Press.1996, 3-6, cited in Arinpe Adejumo,ed. A Postcolonial analysis of the Literary and Cultural Consequences of the abolition of the $18^{\text {th }}$ century transatlantic slave trade on the Yoruba of southwestern Nigeria. LUMINA, 21( 2), 2094-1188

Adejumo, A. (2007). Satire as a form of Social Control: Its Manifestations in Yoruba ritual and festival Songs. Orita: Ibadan Journal of Religious Studies, XXXIX.

Adekoya, A \& Abdul-Rasak, N. (2016). Effect of Crime on Poverty in Nigeria. Romanian Economic and Business Review. Cited in C.O. Iheonu and N.E. Urama. (2019). Addressing Poverty Challenges in Nigeria. Afriheritage Policy Brief. African Heritage Institution.

Adewale, S.A. (1994). Crime and African Traditional Religion. In Orita: Ibadan Journal of Religious Studies, XXVI/1-2.

Aigbovo, O. \& Eidenoje, O. (n.d.). Theorising Nigerian Crime Problems. [Available online at http://dx.org/10.4314/mir.v10i1.7. Retrieved 23/9/2021].

Ajaegb, O.O. (2012). Rising Youth Unemployment and Violent Crime in Nigeria. American Journal of Issues and Humanities, 2(5).

Ayantayo, J.K. (1999). Religious Ethical Issues in the oath of the Nigerian Constitution. In Orita: Ibadan Journal of Religious Studies, XXIV.

Clifford, W. (1974). An Introduction to Africa Criminology, Nairobi: African University Press.

Clinard, M.B. \& Meier, R.F. (2011). Sociology of Deviant Behaviour (14 ${ }^{\text {th }}$ Edition) Belmont, CA: Wordsworth Cengage. ). In M.D. Hussein, Mukhtar, J.I. and Umar, M.B. (2007). Drug-Crime Nexus Nigerian Youths: A Solution through Crime Prevention Strategy. KASU Journal of Social Sciences.

Dukku, A.M. (2012). The Availability-proneness theory: The Gadagi Experience in Kano, Nigeria. Bayero Sociologist: A Journal of Sociological Studies, 1(3).

Egwu, S. (2003). Armed Robbery in the Southwestern States of Contemporary Nigeria Contemporary Nigeria: A Criminal and Criminology Analysis. 
Escareno, A.H. (n.d.). The Cause of Crime. The Scottish Centre for Crime and Justice Research. $S C C J R$. What is crime? University of Glasgow School of Education.

Fagan. P F. The Root Causes of Violent Crime: The Breakdown of Marriage, Family and Community. [Available online at http:www.heritage.orgedu/bpi/pdfs/crime report.pdf].

Familusi, O.O. \& Oke, O.P. (2011). A Christian Dimension to Poverty Discourse in Nigeria. Orita:Ibadan Journal of Religious Studies, University of Ibadan.XL111/2.

Fayemi, E.B. (2019). Shame! Vanguard. [Available online at https://www.vanguardngr.com/2019/09/shame]. Retrieved 25/9/2021.

Federal Ministry of Health. (2005). National Drug Policy 2005. Federal Ministry of Health, in Collaboration with World Health Organisation. In M.D. Hussein, J. I. Mukhtar and M.B. Umar, 2007. Drug-Crime Nexus Nigerian Youths: A Solution through Crime Prevention Strategy. KASU Journal of Social Sciences.

Friday, O. \& Eze, E. O. (2019). Crime Control in Traditional African Societies: A Review of Crime Control in Nigeria. In Journal of Social Service and Welfare, 1(2).

Giddens, A., Duneier, M. \& Appelbaum, R. (2006).Essential of Sociology, Instructor's Review Copy, New York. W.W. Norton \& Company, 134.

Girla, L. \& Rub, J. (2015). White Collar Crime: Definitional Issues and Classification. Revista Nationala De Drept. Retrieved 15/9/2021.

Jensen, G. \& Brownfield, D. (1986). Gender, lifestyles, and victimization: Beyond routine activity theory, Violence and Victims, 14, 85-99.

Karofi, U.S. (2010). Drug-crime nexus: An alternative explanation. Bayero Sociologist: A Journal of Sociological Studies, 1(3).

Kroese, J. et.al. (2020). Growing up in Single- Parent Families and the Criminal Involvement of Adolescents: A Systematic Review. Psychology, Crime and Law. United Kingdom. Informa U.K. Limited, Trading as Taylor \& Francis.

Lamber, E.C. \& Elechi, O.O. (2009). Formal and Informal Crime Control View in Nigeria \& USA. An Exploratory Study among College Students, Journal of Ethnicity in Criminal Justice, 8(2).

Lumun, A.N. et.al. (2013). The Effects of Armed Robbery in Nigeria. IOSR Journal of Humanities and Social Science (IOSR-JHSS), 11(3). (May. - Jun. 2013), 57-59.

Mukherjee, S.K. et.al. (1987). The Size of the Crime Problem in Australia, Australian Institute of Criminology, Canberra.

Nicolaides, A. \& Tornam Duho, KC. (2019). Effective Leadership in Organizations: African Ethics and Corruption, Modern Economy 10(07), 1713-1743. DOI: 10.4236/me.2019.107111

Nicolaides, A. (2015). The paradox of Business Ethics, Quality and Leadership: the path to business sustainability, African Journal of Hospitality, Tourism and Leisure, 4(1), 1-20. 
Nicolaides, A. (2014) Utilizing Ubuntu to Inform Chief Executive Officer (CEO) Thinking on Corporate Social Responsibility (CSR) and Codes of Ethics in Business, Journal of Social Sciences, 41(1), 17-25, DOI: 10.1080/09718923.2014.11893337

Okafor, E.E. (2005). Executive Corruption in Nigeria: A Critical Overview of its Socio-Economic Implications for Development, Alt. J. Psychology Studies Association, 8(1), 21-41.

Okafor, E.E. (2011). Youth Unemployment and Implications for Stability of Democracy. In Nigeria journal of Sustainable Development in Africa, 13(1).

Oke, O.P. (2017). Edi Festival Songs and the control of Deviant Behaviours in Traditional Marriage Institution in Origbo-Meje, Osun State. A Ph.D Thesis Submitted to the Department of Religious Studies, University of Ibadan.

Okolo, G.U. (2002). Social Work: An Introductory Analysis, Calabar: University of Calabar Press.

Olaoba, O.B. (2002). Yoruba Indigenous Court. In Yoruba Legal Culture, Ibadan: FOP Press.

Oludayo, T. (2019). How Traditional Beliefs and Systems are used to fight crime in parts of Lagos. The Conversation: Academic Rigour, Journalist Flair.

Olufayo, O.O. and Jegede, L. I. (2014). Redressing Security and Crime in Nigeria through Traditional Yoruba Social Values and Cultural Practices. Developing Country Studies, 4(4).

Olufayo, O.O. \& Jegede, L.I. (2014). Redressing Security and Crime in Nigeria through Traditional Yoruba Social Values and Cultural Practices. Developing Country Studies, 4(4).

Olukunle, O. (1986). Ethical Revolution: The Newest Doubtful Craze in Town. In Abogunrin, S.O. (Ed.) Religion and Ethics in Nigeria. Ibadan: Daystar Press.

Omoniyi, M. (2013). The Role of Education in Poverty Alleviation and Economic Development: A theological Perspective and Counselling implications. British Journal of Arts of Arts and Social Sciences, 15(11).

Onyima, B.N. (n.d.). Traditional Methods of Social Control in Afikpo North Local Government Area, Ebonyi State: Southeastern Nigeria.

Otu, S.E. \& Elechi, O.E. (2015). Pathways and trajectories to life-course persistent armed robbery offending behaviour in contemporary Nigeria: Examining the predictors and the risks factors, International Journal of Criminal Justice Sciences, 10(1), 10 - 31.

Owumi. B. \& Olusegun, J. O. (2013). Traditional Values, Beliefs and Reliance on Indigenous Resources for Crime Control in Modern Southwest Nigeria. African Journal Review, 7(1), No.28.

Scott, J. \& Marshall, G. (2005). Oxford Dictionary of Sociology. New York: Oxford University Press. Cited in O.O. Familusi and O.P.Oke. (2011). A Christian Dimension to Poverty Discourse in Nigeria. Orita: Ibadan Journal of Religious Studies, University of Ibadan, XL111/2.

Siro, A.A. (2014). Drug Abuse and Political Thuggery among the Youth in Kano Metropolis: A Modern Civilisation or Resource Mismanagement? Journal of Studies in Social Sciences. Vol.7 
(2). In Hussein, M.D, Mukhtar, J.D. and M.B. Umar, M.B. (2007). Drug-Crime Nexus Nigerian Youths: A Solution through Crime Prevention Strategy. KASU Journal of Social Sciences.

Skidmore, B.A. \& Thackeray, M.G. (1982). Introduction to Social Work, New Jersey: PrenticeHall.

The Scottish Centre for Crime and Justice Research. SCCJR. What is crime? University of Glasgow School of Education.

Thotakur, S. (2014). Crime: A Conceptual Understanding: Crime, Criminology, Causes and Types. [Available online at www.researchgate.net/publications/270238380]. Retrieved on $11 / 8 / 2021$

Uchah, C. (2010). Poverty in Nigeria: Some Dimensions and Contributing Factors. Global Majority E-Journal,1(1).

Ugwuoke, C.U. (2011). Nigeria and the menace of kidnapping. The way forward. The Nigerian Journal of Research and Production, 18(2), 1-14).

Ugwuoke,C. U. (2002). Methods of Crime and Social Control in Nigeria. A Traditional Perspective. In Onwuka, O.J. (ed.) Nigeria Peoples and Cultures: Historical and Socio-Structural Perspectives. Enugu, Echrisi and Company, Nigeria. 